\title{
MEMBENTENGI DIRI DENGAN EDUKASI PADA MASA PANDEMI COVID-19
}

\author{
Dhita Krisdamayanti ${ }^{1}$, Hesti Pujiwati ${ }^{2}$
}

\footnotetext{
${ }^{1}$ Fakultas Ekonomi, Universitas Bengkulu, Bengkulu, Indonesia

${ }^{2}$ Fakultas Pertanian, Universitas Bengkulu, Bengkulu, Indonesia

E-mail : hesti_pujiwati@unib.ac.id

Received September 2020, Accepted October 2020
}

\begin{abstract}
ABSTRAK
Program pengabdian dalam pelaksanaan KKN Mandiri 91 Universitas Bengkulu ini bertujuan untuk memberikan edukasi kepada masyarakat tentang pentingnya menjaga kesehatan dan proteksi diri dari penularan virus Corona serta menjadikan masyarakat yang lebih produktif dengan cara melakukan pengembangan diri selama beraktivitas di rumah. Program yang dilaksanakan didasarkan pada kurangnya edukasi yang tepat sehingga banyak masyarakat yang menyalahartikan dan menyalahgunakan informasi yang beredar. Selain itu, physical distancing menyebabkan terbatasnya aktivitas dan mobilitas sehingga banyak masyarakat yang merasa jenuh dalam menjalankan aktivitasnya di rumah. Maka dari itu, dilaksanakanlah program kerja yang dijalankan dengan metode luar dan dalam jaringan yaitu pembuatan artikel opini yang berjudul "Dilema saat Olahraga: Pakai Masker atau Tidak?", pamflet New Normal Starter Pack, dan video informatif yang berjudul "Produktif \#DiRumahAja 101: 5 Website Online Learning untuk Meningkatkan Skill" dan "Produktif \#DiRumahAja 101: 5 Aplikasi Legal untuk Membaca Buku Favoritmu". Hasil dari pengabdian menunjukkan dampak positif bagi penerima informasi yang umumnya adalah pengguna internet dan pengunjung Pasar Tradisional Modern Kota Bengkulu (khusus untuk pembagian pamflet New Normal Starter Pack).
\end{abstract}

Kata Kunci : Covid-19, New Normal, Pengembangan Diri

\section{ABSTRACT}

FORGING YOURSELF WITH EDUCATION DURING THE PANDEMIC COVID-19. This community service program in implementing KKN Mandiri 91 Universitas Bengkulu aims to provide education to the public about the importance of maintaining health and self-protection from transmission of the Corona virus and making people more productive by developing themselves during activities at home. The program implemented is based on a lack of proper education so that many people misinterpret and misuse the information circulating. In addition, physical distancing causes limited activity and mobility so that many people feel bored in carrying out their activities at home. Therefore, a work program carried out with external and network methods was carried out, namely the production of an opinion 
article entitled " Dilema saat Olahraga: Pakai Masker atau Tidak?", The New Normal Starter Pack pamphlet, and an informative video entitled" Produktif \#DiRumahAja 101: 5 Website Online Learning untuk Meningkatkan Skill "and" Produktif \#DiRumahAja 101: 5 Aplikasi Legal untuk Membaca Buku Favoritmu". The results of this dedication show a positive impact on the recipients of information, who are generally internet users and visitors to the Modern Traditional Market in Bengkulu City (specifically for the distribution of the New Normal Starter Pack pamphlet).

Keywords : Covid-19, New Normal, Personal Development

\section{PENDAHULUAN}

Di seluruh belahan dunia, tidak terkecuali di Indonesia, pandemi Covid-19 merupakan penyakit yang tingkat penyebarannya semakin tinggi. Penyakit ini disebabkan oleh virus Severe Acute Respiratory Syndrome Coronavirus 2 (SARS-Cov-2) yang menyerang sistem pernapasan dan umumnya menyebar melalui tetes air yang dikeluarkan ketika bersin, batuk, atau berbicara. Selain itu, penularan juga bisa terjadi ketika menyentuh permukaan yang terkena tetesan air pasien yang terinfeksi kemudian menyentuh mata, mulut, atau hidung dengan tangan yang tidak terbasuh dengan benar [WHO, 2020]. Dengan cara penyebaran virus yang sedemikian cepat, kurangnya data yang tersedia mengenai virus tersebut, dan belum ditemukannya cara penanganan yang efektif menyebabkan tingkat infeksi terus meningkat. Sehingga ada banyak kebijakan-kebijakan dibentuk untuk dapat menekan tingkat infeksi di berbagai negara, contohnya adalah pemberlakuan physical/social distancing dan lockdown (Mossong et al, 2020). Kebijakan tersebut diyakini dapat mengurangi penyebaran Covid-19.

Selama pemberlakuan kebijakan tersebut, banyak informasi menyebar melalui media massa yang terkait dengan kegiatan-kegiatan bermanfaat yang dilakukan pada masa pandemi Covid-19. Kegiatan tersebut diantaranya adalah berolahraga ringan, melakukan pengembangan diri, membaca buku, dan lain sebagainya. Namun diantara banyaknya penyebaran informasi yang ada, masih banyak informasi yang diragukan validitasnya sehingga dapat disalahartikan bahkan disalahgunakan oleh masyarakat yang tidak mampu memfilter informasi dengan baik. Selain itu, ada pula informasi yang tidak tersebar dengan baik sehingga tidak mampu menyentuh seluruh lapisan masyarakat. Akibatnya, penyalahgunaan informasi menjerumuskan pada pelanggaran hak cipta dan informasi yang disalahartikan menyebabkan miskomunikasi.

Menurut Pasal 1 ayat 1 Undang-undang Hak Cipta (UUHC), Hak Cipta adalah hak eksklusif pencipta yang timbul secara otomatis berdasarkan prinsip deklaratif setelah suatu ciptaan diwujudkan dalam bentuk nyata tanpa mengurangi pembatasan sesuai dengan ketentuan peraturan perundang-undangan. Cakupan karya yang dilindungi oleh UUHC adalah karya cipta di bidang ilmu pengetahuan, seni, dan sastra 
yang direalisasikan dalam bentuk nyata. Dalam hal ini, buku dan e-book merupakan karya yang dilindungi oleh UUHC. Seruan dari penulis buku kenamaan, Dewi Lestari, menyatakan keresahan melalui laman Instagramnya (1/4/2020) tentang pelanggaran hak cipta yang marak terjadi di masyarakat pada masa pandemi Covid-19 (Kompas.com, 2020). Disampaikan pula oleh Kepala Subdirektorat Pelayanan Hukum Direktorat Hak Cipta, Direktorat Jenderal Kekayaan Intelektual (DJKI) Agung Damarsasongko bahwa tindakan penyebaran e-book secara ilegal merupakan bentuk pelanggaran baru di era digital (detikNews, 2020). Pelanggaran hak cipta tersebut dilakukan dengan cara menyebarkan dan mengunggah buku bajakan dalam bentuk e-book, sehingga para penulis yang memiliki hak cipta tersebut merasa dirugikan hak moral dan hak ekonominya. Alasan yang mendasarinya adalah agar masyarakat dapat mengisi waktu luang dengan membaca buku pada saat di rumah untuk menghilangkan kejenuhan.

Serangkaian kebijakan yang dibentuk untuk mengurangi dampak penularan Covid-19 menimbulkan efek pada aspek yang lain, sehingga terbentuklah kebijakan new normal untuk dapat memulihkan kembali aspek-aspek kehidupan yang macet karena pengaruh pandemi. Dengan ini, masyarakat dituntut untuk dapat menyesuaikan diri dengan keadaan normal baru meskipun masih harus berhadapan dengan risiko penularan Covid-19. Sosialisasi protokol kesehatan sangat gencar dilakukan mengenai new normal dan bagaimana cara masyarakat untuk menghadapinya, salah satunya adalah pengenalan atribut yang wajib dimiliki masyarakat saat beraktivitas di luar rumah. Namun pada faktanya, banyak masyarakat yang masih mengabaikan protokol kesehatan yang berlaku.

Melalui tinjauan tersebut, penulis berkesempatan untuk menjadi salah satu agen yang bertanggung jawab dalam mengedukasi masyarakat dan menyebarkan informasi yang seharusnya dapat dicerna baik oleh masyarakat, khususnya dalam hal membentengi kesehatan diri pada masa pandemi Covid-19. Upaya yang dilakukan untuk mencapai misi tersebut direalisasikan dalam tiga program kerja, yaitu pembuatan artikel opini yang berjudul "Dilema saat Olahraga: Pakai Masker atau Tidak?", pamflet New Normal Starter Pack, dan video informatif yang berjudul "Produktif \#DiRumahAja 101: 5 Website Online Learning untuk Meningkatkan Skill" dan "Produktif \#DiRumahAja 101: 5 Aplikasi Legal untuk Membaca Buku Favoritmu". Dengan program-program yang dilaksanakan, masyarakat dapat menjadi lebih produktif dengan cara melakukan pengembangan diri dengan belajar mandiri dan membaca buku selama di rumah saja serta masyarakat yang melek akan pentingnya menjaga kesehatan dan proteksi diri dari penularan virus Corona.

\section{MATERI DAN METODE}

Pelaksanaan kegiatan yang mengacu pada edukasi di masa Covid19 terdiri dari tiga program kerja dengan spesifikasi material dan metode yang berbeda. Uraian metode dan material yang digunakan yaitu: 


\section{Program kerja 1: Pembuatan artikel opini "Dilema saat Olahraga: Pakai Masker atau Tidak?"}

Program kerja ini memfokuskan sasarannya kepada pengguna internet secara umum terutama pengguna Medium. Metode yang digunakan adalah metode dalam jaringan karena penyampaian informasi dilakukan melalui platform Medium. Pelaksanaan program kerja tersebut dilakukan pada 23-27 Juni 2020. Tahapan yang dilakukan untuk menghasilkan hingga mempublikasi artikel tersebut yaitu:

Tabel 1. Tahapan kegiatan program kerja pembuatan artikel opini "Dilema Saat Olahraga: Pakai Masker atau Tidak?"

\begin{tabular}{ll}
\hline \multicolumn{1}{c}{ Tahapan } & \multicolumn{1}{c}{ Kegiatan } \\
\hline Persiapan & $\begin{array}{l}\text { Mengumpulkan informasi yang berasal dari jurnal dan } \\
\text { media pemberitaan yang terpercaya. } \\
\end{array}$ \\
& $\begin{array}{l}\text { Menyusun kerangka karangan dan membentuk paragraf } \\
\text { artikel opini secara utuh. }\end{array}$ \\
Pelaksanaan & Mempublikasikan artikel opini di Medium \\
Evaluasi & Mengamati statistik pengunjung \\
\hline
\end{tabular}

\section{Program kerja 2: Pembuatan pamflet New Normal Starter Pack}

Program kerja ini memfokuskan sasarannya kepada pengunjung dan penjual yang ada di Pasar Tradisional Modern Kota Bengkulu sebagai tempat yang strategis untuk menyebarkan informasi. Metode yang digunakan adalah metode luar jaringan karena penulis menyebarkan langsung pamflet ke lokasi yang sudah ditentukan. Program kerja tersebut dilaksanakan pada 29 Juni - 4 Juli 2020 dengan rincian tahapan pelaksanaan sebagai berikut:

Tabel 2. Tahapan kegiatan program kerja pembuatan pamflet New Normal Starter Pack

\begin{tabular}{ll}
\hline \multicolumn{1}{c}{ Tahapan } & \multicolumn{1}{c}{ Kegiatan } \\
\hline Persiapan & Mengumpulkan informasi. \\
& Membuat rancangan kasar \\
& Mengolah desain pamflet \\
& Mencetak pamflet \\
Pelaksanaan & $\begin{array}{l}\text { Menyebarkan pamflet di Pasar Tradisional Modern Kota } \\
\text { Bengkulu }\end{array}$ \\
\hline
\end{tabular}

Program kerja 3: Pembuatan video informatif "Website untuk pengembangan diri selama \#DirumahAja" dan "Aplikasi legal untuk membaca selama \#DirumahAja"

Sasaran program kerja ini tertuju pada pengguna internet yang menggunakan Youtube. Metode yang digunakan adalah metode dalam 
jaringan karena informasi tersebut disebarluaskan dalam bentuk video yang diunggah di Youtube. Porgram kerja tersebut dilaksanakan pada 6 26 Juli 2020 dengan menhasilkan dua video konten yang berbeda. Rincian tahapan yang dilakukan adalah sebagai berikut:

Tabel 3. Tahapan kegiatan program kerja pembuatan video informatif "Website untuk pengembangan diri selama \#DirumahAja" dan "Aplikasi legal untuk membaca selama \#DirumahAja"

\begin{tabular}{ll}
\hline \multicolumn{1}{c}{ Tahapan } & \multicolumn{1}{c}{ Kegiatan } \\
\hline Persiapan & Mengumpulkan informasi \\
& Merancang konsep dan desain video \\
& Mengolah desain di Ms. Powerpoint \\
& Menambahkan narasi di video dan menyimpan video \\
& dalam format mp4. \\
Pelaksanaan & Publikasi video di kanal Youtube pribadi. \\
Evaluasi & Mengamati statistik penonton dan mengajukan \\
& kuisioner untuk menguji kebermanfaatan video \\
& konten.
\end{tabular}

\section{HASIL DAN PEMBAHASAN}

\section{Program kerja 1: Pembuatan artikel opini "Dilema saat Olahraga: Pakai Masker atau Tidak?"}

Artikel tersebut dipublikasi pada tanggal 27 Juni 2020. Karena media tersebut baru pertama kali digunakan, cara penulis dalam menarik minat pengunjung untuk membaca artikel tersebut adalah menyebarkan tautan tersebut di WhatsApp dan Instagram dan menggunakan tagar yang berkaitan dengan topik artikel tersebut. Dengan promosi manual yang dilakukan, perolehan statistik beserta pembahasannya dibahas sebagai berikut:

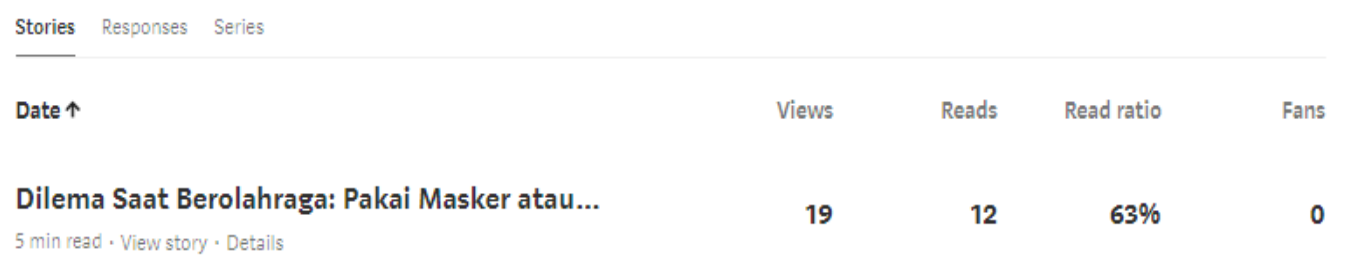

Gambar 1. Statistik artikel opini "Dilema saat Olahraga: Pakai Masker atau Tidak?" per 7 Agustus 2020.

1) 5 min read menyatakan bahwa estimasi durasi baca rata-rata artikel tersebut adalah 5 menit.

2) Views adalah total pengunjung yang melihat artikel tersebut. Dengan angka perolehan sebanyak 19 views, menyatakan bahwa artikel tersebut telah diakses oleh pengunjung sebanyak 19 kali. 
3) Reads adalah total pengunjung yang membaca artikel tersebut sesuai dengan estimasi durasi rata-rata atau membaca artikel tersebut sampai habis. Sesuai dengan hasil perolehan statistik, total artikel tersebut dibaca oleh pengunjung adalah 12 kali.

4) Read ratio adalah rasio antara total views dan reads. Seperti yang telah dijabarkan pada poin kedua dan ketiga, terdapat kesenjangan antara jumlah total penanyangan dan total dibaca sehingga read ratio yang didapatkan adalah $63 \%$. Menurut penulis, ada tiga kemungkinan mengapa terdapat kesenjangan pada dua aspek tersebut, yaitu pengunjung tidak membaca artikel sampai habis, hanya berkunjung, atau tidak mencapai estimasi durasi baca rata-rata artikel tersebut.

5) Fans adalah pengunjung yang memberikan applause atau menyukai artikel tersebut. Seperti data yang telah dilampirkan, tidak ada pengunjung yang tercatat pada aspek ini. Hal ini disebabkan karena pengunjung yang membaca artikel tersebut tidak memiliki akun Medium sehingga tidak dapat memberikan applause.

\section{Program kerja 2: Pembuatan pamflet New Normal Starter Pack}

Pamflet tersebut dicetak sebanyak 50 lembar dengan kertas A4, kemudian disebarkan langsung oleh penulis pada hari Sabtu, 4 Juli 2020 di Pasar Tradisional Modern Kota Bengkulu. Alasan penulis memilih lokasi tersebut sebagai tempat menyebarkan pamflet adalah karena pasar merupakan tempat yang berpotensi menimbulkan keramaian, sehingga dapat mempermudah penyebaran informasi kepada masyarakat. Penyebaran pamflet tidak hanya dilakukan dengan menempelkannya di dinding, namun juga memberikannya kepada penjual dan pembeli sekaligus menjelaskan informasinya. Dengan adanya informasi tersebut, setiap pengunjung yang ingin melakukan aktivitas di luar ruangan dapat selalu mempersiapkan barang-barang pribadi yang mereka miliki sebagai bentuk proteksi diri terhadap virus Corona di masa new normal.

\section{Program kerja 3: Pembuatan video informatif "Website untuk pengembangan diri selama \#DirumahAja" dan "Aplikasi legal untuk membaca selama \#DirumahAja"}

Video ini membahas tentang 5 situs pembelajaran daring yang dapat dijadikan sebagai sarana pengembangan diri selama masa Covid19 dan 5 aplikasi legal yang dapat digunakan untuk membaca buku beserta fitur-fitur yang ditawarkan oleh beberapa aplikasi di dalamnya. Dengan ini, masyarakat tetap dapat meningkatkan produktivitas diri dengan hanya beraktivitas di rumah saja dan mengurangi intensitas untuk beraktivitas di luar rumah selagi tidak perlu. Metode sosialiasi yang digunakan adalah menyebarkan tautan video di WhatsApp dan Twitter. Berdasarkan uraian beberapa komponen metrik di Youtube Analytics oleh Keyhole, komponen yang dievaluasi untuk mengukur perkembangan video tersebut meliputi:

1) Views adalah total penayangan video. 
2) Watch time adalah total waktu (dalam menit) yang diluangkan penonton untuk menyaksikan video.

3) Subsribers adalah jumlah penonton yang mengikuti kanal YouTube.

4) Average view duration adalah durasi rata-rata penayangan video.

5) Impressions adalah total berapa kali calon penonton melihat thumbnail video saat berada di YouTube.

6) Impression click-through rate adalah total persentase impresi yang berubah menjadi view. Dengan kata lain, impression click-through rate akan bertambah apabila penonton mengklik video tersebut setelah melihat thumbnail.

Dengan komponen yang telah dijabarkan di atas, hasil statistik yang diperoleh adalah sebagai berikut:

Tabel 4. Perbandingan hasil statistik video "Website untuk pengembangan diri selama \#DirumahAja" dan "Aplikasi legal untuk membaca selama \#DirumahAja"

\begin{tabular}{|c|c|c|}
\hline \multirow[b]{2}{*}{ Komponen } & \multicolumn{2}{|c|}{ Hasil yang diperoleh (per 7 Agustus 2020) } \\
\hline & $\begin{array}{l}\text { Website untuk } \\
\text { pengembangan diri } \\
\text { selama \#DirumahAja }\end{array}$ & $\begin{array}{l}\text { Aplikasi legal untuk } \\
\text { membaca selama } \\
\text { \#DirumahAja }\end{array}$ \\
\hline Tanggal publikasi & 15 Juli 2020 & 26 Juli 2020 \\
\hline Views & 70 views & 48 views \\
\hline Watch time & 1.6 jam & $1.2 \mathrm{jam}$ \\
\hline Subscribers & 2 subscribers & 2 subsribers \\
\hline Average view & 1 menit 21 detik & 1 menit 30 detik \\
\hline Impressions & 48 kali & 47 kali \\
\hline $\begin{array}{l}\text { Impressions click- } \\
\text { through rate }\end{array}$ & $42.9 \%$ & $19.2 \%$ \\
\hline
\end{tabular}

\section{Evaluasi melalui Survei Kebermanfaatan Konten Video Informatif dalam Mendukung Produktivitas Selama Masa Pandemi Covid-19}

Sebagai evaluasi dan tindak lanjut dari publikasi video konten, penulis mengadakan survei melalui Google Form yang berisi berbagai pertanyaan yang berkaitan dengan video informatif yang telah dipublikasi. Survei tersebut dilaksanakan pada 28-29 Juli 2020 dan disebarkan kepada pengguna internet secara umum melalui WhatsApp, Instagram dan Twitter dan berhasil menarik responden sebanyak 63 orang. Hasil dari survei menggambarkan keberagaman tingkat penerimaan informasi pada sebelum dan sesudah menyaksikan kedua video konten tersebut. Kesimpulan dari survei menyatakan bahwa video konten tersebut telah memberikan dampak positif terhadap responden. 


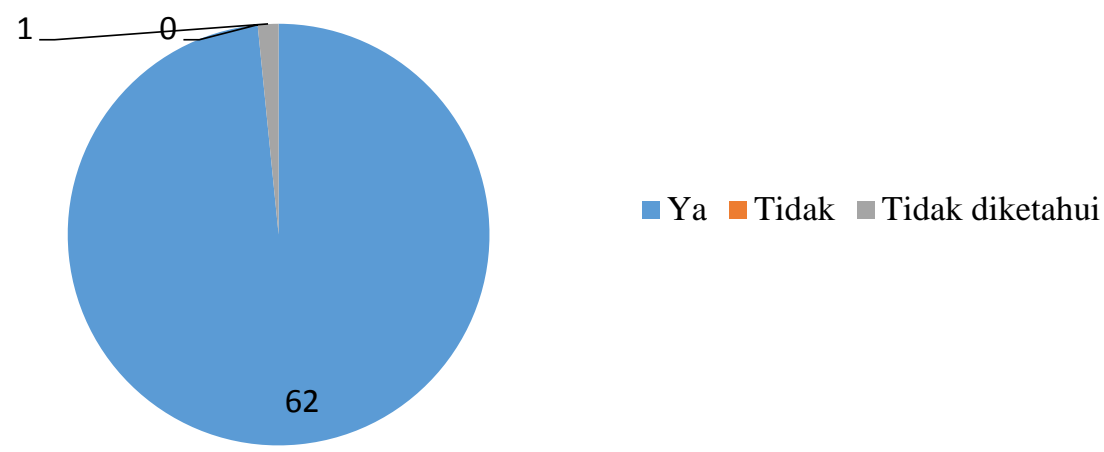

Gambar 2. Hasil statistik dari pertanyaan apakah video "Produktif \#DiRumahAja 101: 5 Website Online Learning untuk Meningkatkan Skill" memberikan dampak positif.

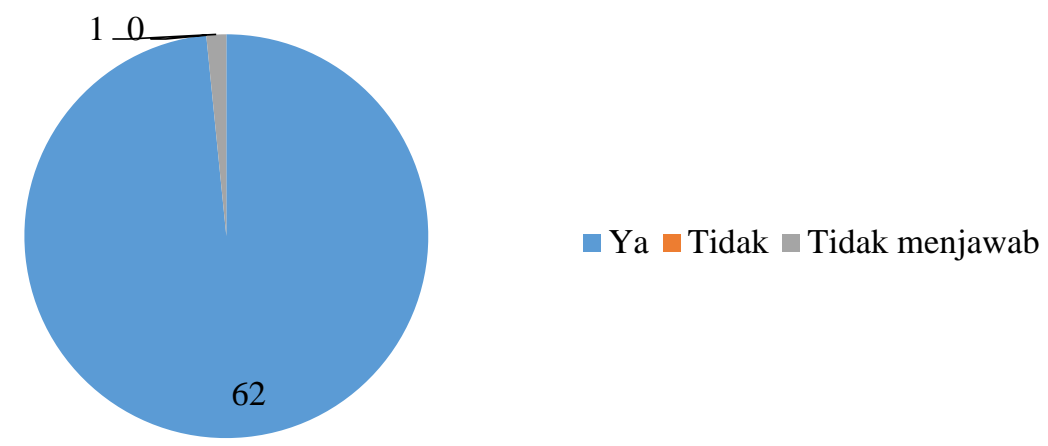

Gambar 3. Hasil statistik dari pertanyaan apakah video "Produktif \#DiRumahAja 101: 5 Aplikasi Legal untuk Membaca Buku Favoritmu" memberikan dampak positif.

\section{KESIMPULAN}

Dalam situasi Covid-19 seperti saat ini, KKN Mandiri merupakan terobosan baru dalam pelaksanaan kuliah kerja nyata sebagai wujud kontribusi kepada masyarakat dalam upaya pencegahan penyebaran Covid-19 yang diadakan oleh Universitas Bengkulu. Salah satu pokok aktivitas yang dilakukan bergerak di bidang komunikasi yang bertujuan untuk mengedukasi masyarakat agar lebih produktif dengan cara melakukan pengembangan diri selama di rumah serta masyarakat yang melek akan pentingnya menjaga kesehatan dan proteksi diri dari penularan virus Corona. Program kerja tersebut adalah:

- $\quad$ Pembuatan artikel opini "Dilema saat Olahraga: Pakai Masker atau Tidak?" yang dipublikasikan di Medium. Tujuannya adalah mengedukasi masyarakat tentang penggunaan masker saat berolahraga, khususnya di luar ruangan.

- Pembuatan pamflet New Normal Starter Pack yang hasilnya disebarkan langsung kepada masyarakat. Tujuannya adalah mengedukasi 
masyarakat tentang barang pribadi apa saja yang harus dipersiapkan dalam menghadapi new normal.

Pembuatan video informatif "Produktif \#DiRumahAja 101: 5 Website Online Learning untuk Meningkatkan Skill" dan "Produktif \#DiRumahAja: 5 Aplikasi Legal untuk Membaca Buku Favoritmu" yang dipublikasikan di YouTube. Tujuannya adalah mengajak masyarakat untuk tetap produktif di rumah dengan cara mengikuti kursus daring dan membaca buku melalui aplikasi yang legal untuk mengurangi kasus penyebaran buku bajakan di internet. Hasil survei yang menguji kebermanfaatan video informatif tersebut kepada pengguna internet menyatakan bahwa kedua video tersebut memiliki dampak yang positif.

\section{DAFTAR PUSTAKA}

detikNews. 2020. Bosan Lalu Download \& Sebarkan e-Book llegal, Hatihati Bisa Dipenjara. Diakses pada 9 September 2020, dari https://news.detik.com/berita/d-4984305/bosan-lalu-download-ebarkan-e-book-ilegal-hati-hati-bisa-dipenjara

Keyhole. 2019. Youtube Analytics: 21 Metrics That You Should Track. Diakses pada 13 September 2020, dari https://keyhole.co/blog/youtube-analytics/ .

Kompas.com. 2020. Dewi Lestari Serukan Jangan Unggah Buku PDF llegal. Diakses pada 9 September 2020, dari https://www.kompas.com/hype/read/2020/04/01/190436866/dewilestari-serukan-jangan-unggah-buku-pdf-ilegal.

Mossong J, Hens N, Jit M, , Social contacts and mixing patterns relevant to the spread of infectious diseases. PLoS Med2008;5:e74. doi:10.1371/journal.pmed.0050074. pmid:1836625 2 Undang-Undang Hak Cipta Nomor 28 Tahun 2014, Pasal 1 hal. 2.

World Health Organization. 2020. Coronavirus Disease (COVID-19) advice for the public: Mythbusters. Diakses pada 7 September 2020, dari https://www.who.int/emergencies/diseases/novel-coronavirus2019/advice-for-public/myth-busters. 